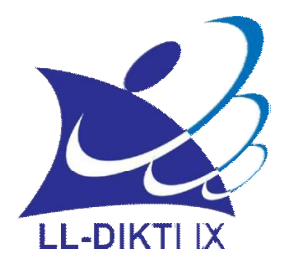

\title{
Kontribusi Koordinasi Mata Tangan, Kekuatan Lengan, Panjang Lengan Terhadap Kemampuan Dribble Pada Permaian Bola Basket.
}

\author{
Andi Hasriadi Hasyim \\ Pendidikan Jasmani Kesehatan dan Rekerasi, STKIP YPUP Makassar \\ Email: andihasriadi41@gmail.com
}

\begin{abstract}
Artikel info
Artikel history:

Received; 08-07-2019

Revised:10-08-2019

Accepted;9-9-2019

Abstract. This study aims to prove the contribution of hand eye coordination, arm strength, arm length to dribble abilities in basketball. The method in this study is descriptive with a sample of 30 male students. Testing the hypothesis in this study is a correlation analysis test. The results showed, eye hand coordination, arm strength, arm length proved to have a contribution to the ability of dribble in basketball with a coefficient of $70.12 \%$. To determine and search for talent, athletes need to pay attention to the factors of eye hand coordination, arm strength and arm length, especially in the basic technique of basketball, namely dribble.
\end{abstract}

\begin{abstract}
Abstrak. Penelitian ini bertujuan untuk membuktikan kontribusi koordinasi mata tangan, kekuatan lengan, panjang lengan terhadap kemampuan dribble pada permainan bola basket. Metode dalam penelitian ini adalah deskriptif dengan sampel penelitian berjumlah 30 siswa putra. Pengujian hipotesis dalam penelitian ini adalah uji analisis korelasi. Hasil penelitian menujukkan, koordinasi mata tangan, kekuatan lengan, panjang lengan terbukti ada kontribusi terhadap kemampuan dribble pada permainan bola basket dengan nilai koefisien 70,12\%. Untuk menentukan dan pencarian bakat atlet perlu memerhatikan faktor koordinasi mata tangan, kekuatan lengan dan panjang lengan terkhusus pada teknik dasar permainan bola basket yaitu dribble.
\end{abstract}

Keywords:

Koordinasi Mata Tangan

Coresponden author:

Email: andihasriadi41@gmail.com

Kekuatan Lengan

Panjang Lengan

Dribble

\section{PENDAHULUAN}

Cabang olahraga bola basket di Indonesia berkembang sangat baik di masyarakat dan digemari oleh semua kalangan dan usia. Terbukti bahwa munculnya beberapa klub serta atlet- 


\section{Jurnal Celebes Education}

atlet berbakat baik tingkat perguruan tinggi maunpun tingkat sekolah. Olahraga bola basket merupakan aktivitas yang sangat kompleks, mulai dari berjalan, berlari, melompat, dan menangkap. Keterampilan teknik dasar pada permainan bola basket adalah menggiring bola, mengoper bola, menerima bola, pivot, menembak, dan olah kaki (Ahmadi, 2007).

Sekolah merupakan sumber populasi dan potensi dalam pembinaan olahraga. Pembinaan olahraga pada siswa merupakan salah satu program dari kementerian pemuda dan olahraga dan instansi terkait dalam pencarian bibit atlet yang dapat menunjang prestasi olahraga nasional (UU SKN No 3 Th 2005 Pasal 1 ayat 3). Ketersediaan fasilitas serta dana pembinaan yang menunjang merupakan salah satu faktor untuk menghasilkan atlet potensial (Wibisono, 2011). Pembibitan dapat dilakukan dengan mengidentifikasi serta dilanjutkan dengan tahap pengembangan (Islahuzaman, 2010). Melalui kegiatan ekstrakulikuler di sekolah, merupakan salah satu cara mencari atlet yang berbakat serta siswa mampu mengembangkan potensi dan kemampuan bermain. Fenomena yang terjadi, guru serta pelatih ataupun pencari bakat tidak memerhatikan hal tersebut. Oleh sebab itu eksistensi tim sekolah dalam mengikuti tournamen ternyata tidak mampu memberikan banyak prestasi di bidang olahraga bola basket.

Hal yang mendasar dalam permainan bola basket adalah kemampuan untuk mendribbling bola. Dribble merupakan salah satu teknik dasar yang paling dominan dalam permainan bola basket. Dribble pada dasarnya merupakan gerakan yang mengarah pada ring (Kosasih, 2010). Pada hakikatnya permainan bola basket adalah olahraga yang membutuhkan keterampilan tinggi. Kemampuan dribble untuk ball handling bukan hanya sebagai pelengkap namun juga berpengaruh pada saat tim melakukan penyerangan (Nurhidayah \& Sukoco, 2015). Dribble merupakan salah satu dasar yang harus diketahui dan diperkenalkan kepada pemain tingkat pemula, karena keterampilan ini sangat penting dalam pertandingan bola basket (Oliver, 2007). Beberapa indikator komponen biomotor yang dapat mempengaruhi dribbling bola pada permainan bola basket yaitu koordinasi mata tangan, kekuatan otot lengan, dan panjang lengan (Sukadiyanto \& Muluk). Untuk menjadi pemain yang baik perlu melakukan dribble dengan tangan manapun, baik tangan yang kuat maupun yang lemah (Wissel, 2000).

Koordinasi mata tangan sangat berpegaruh pada permainan bola basket. Ketepatan dan akurasi dapat diartikan sebagai kemampuan menempatkan suatu obyek pada sasaran tertentu (Haryono, 2009). Koordinasi merupakan kemapuan menjalankan tugas gerak dengan melibatkan unsur mata, tangan, dan kaki (Suharjana, 2013). Tingkat koordinasi atau baik tidaknya koordinasi gerak seseorang tercemin dalam kemampuannya untuk melakukan suatu gerakan secara mulus, tepat dan efisien. Seorang atlet dengan koordinasi yang baik akan mampu 
Kemampuan Dribble Permainan Bola Basket (Hasriadi) | 42

melakukan keterampilan dengan sempurna juga mudah dan cepat dalam melakukan keterampilan yang masih baru. Atlet juga dapat dengan mudah berpindah atau mengubah pola gerakannya dari pola gerak yang satu ke pola gerak yang lain sehingga geraknya menjadi efisien.

Kejuatan otot lengan sangat penting pada saat mendribble bola. Besarnya dorongan bola saat dipantulkan akan lebih kuat sehingga bola akan sulit di rebut oleh lawan. Kekuatan adalah kemampuan otot untuk berkontraksi untuk melawan beban secara maksimal (Ismaryanti, 2008). Panjang lengan merupakan bagian dari struktur tubuh atau postur tubuh yang ada pada seorang atlet dan termasuk dalam anthropometrik sebagai alat ukur. Lengan adalah pergerakan yang digunakan pada permainan Bolabasket. Bolabasket merupakan permainan yang menggunakan bola basket dan digerakkan oleh pergelangan tangan dan lengan. Kondisi fisik seseorang dalam hal ini susunan tubuh secara keseluruhan, panjang lengan dikategorikan sebagai panjang tubuh, seperti yang dikemukakan oleh Pasau (1986) bahwa ; a) Ukuran panjang tubuh (length wise growth) meliputi: tinggi badan, tinggi duduk, panjang tungkai, lengan, kaki, jari-jari, leher dan lain-lain. b) Ukuran besar tubuh (broad wise growth) meliputi: lingkar dada, kepala, leher, lengan, paha, perut, pinggul dan lain-lain. c) Amount growth: yaitu berat badan.

Tujuan dari penelitian ini adalah untuk membuktikan pengaruh koordinasi mata tangan, kekuatan otot lengan, dan panjang lengan terhadap kemampuan dribble bola pada permainan bola basket.

\section{METODE}

Jenis penelitian dalam penelitian ini yaitu bersifat deskriptif dengan desain penelitian sebagai berikut :

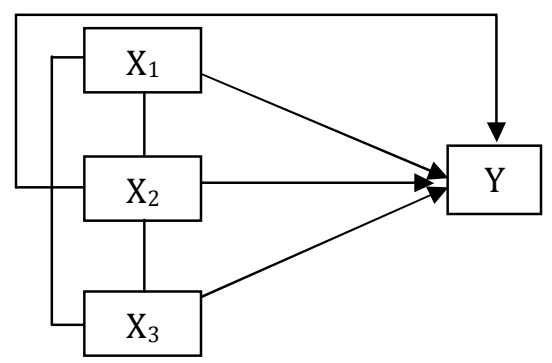

Gambar 1. Desain Penelitian

$$
\begin{array}{ll}
\mathrm{X} 1 & \text { : Koordinasi mata tangan } \\
\mathrm{X} 2 & \text { : Kekuatan lengan } \\
\mathrm{X} 3 & \text { : Panjang lengan } \\
\mathrm{Y} & \text { : Kemampuan dribble }
\end{array}
$$




\section{Jurnal Celebes Education}

Penelitian ini memiliki dua variable yang terlibat, yakni variable bebas yaitu koordinasi mata tangan, kekuatan lengan, panjang lengan, dan variable terikat yaitu kemampuan dribble. Lokasi dalam penelitian ini adalah SMA Negeri 2 Bone dengan sampel penelitian berjumlah 30 siswa putra. Teknik pengambilan sampel secara simple random sampling. alat dan bahan dalam penelitian ini adalah bola tenis, cone, stopwatch, kapur, pipa, sasaran, meteran, alat tulis dna formulir tes.

Pengukuran koordinasi mata tangan dilakukan dengan cara sampel penelitian memantulkan bola ke tembok atau dengan gerakan passing kearah sasaran kemudian sampai batas waktu yang telah ditentukan. Pengukuran kekuatan lengan dilakukan dengan cara sample penelitian melakukan mengambil posisi push up dan dilakukan selama 30 detik Pengukuran panjang lengan dilakukan cara sampel penelitian berada pada posisi sikap berdiri tegak, lengan lurus kesamping badan kemudian dilakukan pengukuran yang dimulai dari persendian antara bahu dengan lengan atas atau tulang acromion pada ujung jari tengah atau ujung jari yang terpanjang. Pengukuran kemampuan dribble dilakukan dengan cara sampel penelitian menggiring bola sesuai dengan alur yang telah ditentukan.

Data yang diperoleh dalam penelitian ini akan dianalisis secara statistik deskriptif dengan menggunakan aplikasi program SPPS (Statistical Product and Service Solutions).

\section{HASIL DAN PEMBAHASAN}

Data empiris yang diperoleh di lapangan melalui tes dan pengukuran yang terdiri atas: koordinasi mata tangan, kekuatan lengan, panjang lengan dan kemampuan dribble pada permainan bola basket pada siswa SMA Negeri 2 Bone selanjutnya dianalisis dengan menggunakan teknik statistik deskriptif dan statistik inferensial. Analisis data deskriptif dimaksudkan untuk mendapatkan gambaran umum data penelitian, kemudian dilanjutkan dengan pengujian persyaratan analisis yaitu uji normalitas data. Sedangkan analisis data secara inferensial dimaksudkan untuk mendapatkan hasil pengujian hipotesis yang diajukan dalam penelitian adalah uji korelasi.

Tabel 1. NIlai rerata dan standar deviasi variabel penelitian.

\begin{tabular}{lccc}
\hline Variabel & $\mathrm{N}$ & Rerata \pm SD & $\mathrm{P}$ \\
Koordinasi mata tangan (X1) & 30 & $12.93 \pm 2.36$ & $0.23^{*}$ \\
Kekuatan Lengan (X1) & 30 & $19.17 \pm 2.86$ & $0.30^{*}$ \\
Panjang Lengan (X1) & 30 & $57.53 \pm 3.63$ & $0.53^{*}$ \\
Kemampuan Dribble (X1) & 30 & $11.51 \pm 1.05$ & $0.31^{*}$ \\
\hline
\end{tabular}


Kemampuan Dribble Permainan Bola Basket (Hasriadi) | 44

*: Menunjukkan data berdistribusi normal.

Berdasarkan Tabel 1 terlihat bahwa signifikansi data masing-masing kelompok p>0.05. Dengan demikian dapat disimpulkan bahwa sampel penelitian terdistribusi normal. Kesimpulan ini memberikan implikasi bahwa analisis statistika dapat digunakan untuk menguji hipotesis yang diajukan dalam penelitian ini, sehingga syarat pertama untuk pengujian hipotesis telah terpenuhi.

Tabel 2. Hasil pengujian Hipotesis.

\begin{tabular}{lccc}
\hline Variabel & $\mathrm{N}$ & $\mathrm{R}$ & Sig \\
X1 ke Y & 30 & 0.517 & 0.01 \\
X2 ke Y & 30 & 0.509 & 0.01 \\
X3 ke Y & 30 & 0.512 & 0.02 \\
X1, X2, X3 ke Y & 30 & 0.712 & 0.00 \\
\hline
\end{tabular}

Hasil korelasi menunjukkan koordinasi mata tangan (X1) dengan kemampuan dribble (Y) ada kontribusi. Uji korelasi kekuatan lengan (X2) dengan kemampuan dribble (Y) menunjuukan ada kontribusi. Uji korelasi panjang lengan (X3) dengan kemampuan dribble (Y) menunjukkan ada kontribusi. Serta hasil uji korelasi ganda koordinasi mata tangan (X1), kekuatan lengan (X2) dan panjang lengan (X3) dengan kemampuan lompat jauh (Y) menunjukkan ada kontribusi.

Hasil analisis uji korelasi dalam hipotesis perlu dikaji lebih lanjut dan disajikan dengan lengkap. Untuk mengambil kesimpulan penelitian yang sesuai dengan tujuan penelitian, maka hasil analisis data yang perlu dibahas sesuai dengan teori-teori yang mendasarinya. Adapun pembahasan yang dimaksud adalah sebagai berikut:

1. Kontribusi Koordinasi mata tangan dengan Kemampuan dribble pada permainan bola basket.

Dari hasil pengujian hipotesis pertama ditemukan bahwa koordinasi mata tangan memiliki kontribusi dengan kemampuan dribble pada permainan bola basket siswa SMA Negeri 2 Bone. Koefisien determinasi yang diperoleh untuk kontribusi koordinasi mata tangan terhadap kemampuan dribble pada permainan bola basket siswa SMA Negeri 2 Bone 0.51. Menyiratkan pengaruh koordinasi mata tangan terhadap kemampuan dribble pada permainan bola basket sebesar $51.70 \%$.

Koordinasi mata tangan adalah kemampuan mengintegrasikan berbagai gerakan yang berlainan ke dalam satu pola tunggal gerakan. Koordinasi mata tangan dilakukan dengan gerakan passing ke dinding selama waktu yang telah ditentukan. Apabila koordinasi mata 


\section{Jurnal Celebes Education}

tangan kuat, maka tentu akan berpengaruh untuk memberikan hasil yang optimal dalam dribble pada permainan bola basket.

Koordinasi mata tangan merupakan salah satu faktor yang menopang dalam kerja fisik, termasuk dalam kemampuan dribble pada permainan bola basket. Karena dengan koordinasi mata tangan yang baik, akan membantu pada saat melakukan dribble permainan bola basket. Apa yang telah dihasilkan dalam penelitian ini, yang memperlihatkan adanya kontribusi koordinasi mata tangan dengan kemampuan dribble pada permainan bola basket, menjadi rujukan dalam meningkatkan kemampuan dribble pada permainan bola basket di sekolah.

\section{Kontribusi kekuatan lengan dengan Kemampuan dribble pada permainan bola basket}

Dari hasil pengujian hipotesis kedua ditemukan bahwa kekuatan lengan memiliki kontribusi yang signifikan dengan kemampuan dribble pada permainan bola basket siswa SMA Negeri 2 Bone Koefisien determinasi yang diperoleh untuk kontribusi kekuatan lengan terhadap kemampuan dribble pada permainan bola basket siswa SMA Negeri 2 Bone 0,50. Dengan demikian tingkat kontribusi kekuatan lengan terhadap kemampuan dribble pada permainan bola basket sebesar $50,09 \%$.

Pada prinsipnya kekuatan lengan adalah kemampuan seseorang untuk mempergunakan kekuatan lengan yang dikerahkan secara maksimum dalam waktu sependek-pendeknya ketika melakukan dribble dalam olahraga bola basket. sehingga menghasilkan kemampuan dribble pada permainan bola basket yang optimal. Apabila kekuatan lengan dimiliki secara memadai pada saat melakukan kemampuan dribble pada permainan bola basket, maka tentu akan berkontribusi untuk memberikan hasil yang maksimal.

Apabila kekuatan lengan diperhatikan, maka secara fisiologi akan menghasilkan kemampuan dribble pada permainan bola basket yang lebih baik. Kekuatan lengan merupakan prakondisi yang menunjang dalam berbagai cabang olahraga termasuk olahraga bola basket khususnya dribble. Oleh karena dengan kekuatan lengan yang baik sangat mendukung tercapainya hasil dribble yang optimal. Apa yang telah dihasilkan dalam penelitian ini, yang memperlihatkan adanya kontribusi kekuatan lengan dengan kemampuan dribble pada permainan bola basket.

3. Kontribusi panjang lengan dengan Kemampuan dribble pada permainan bola basket

Dari hasil pengujian hipotesis ketiga ditemukan bahwa panjang lengan memiliki kontribusi yang kuat dan signifikan dengan kemampuan dribble pada permainan bola basket siswa SMA Negeri 2 Bone Koefisien determinasi yang diperoleh untuk kontribusi panjang lengan 
Kemampuan Dribble Permainan Bola Basket (Hasriadi) | 46

terhadap kemampuan dribble pada permainan bola basket siswa SMA Negeri 2 Bone sebesar 0,51. Dengan demikian tingkat kontribusi panjang lengan dengan kemampuan dribble pada permainan bola basket sebesar $51,20 \%$.

Panjang lengan bagian dari struktur tubuh atau postur tubuh yang ada pada seorang atlet dan termasuk dalam anthropometrik sebagai alat ukur. Panjang lengan dalam dribble sangat diperlukan untuk memberikan hasil yang optimal. Apabila panjang lengan dimiliki pada dribble maka tentu akan berkontribusi untuk memberikan kemampuan dribble pada permainan bola basket yang baik.

Apabila panjang lengan diperhatikan pada dribble, maka secara fisiologi akan mendorong kemampuan dribble pada permainan bola basket optimal. Panjang lengan merupakan komponen fisik yang sangat penting dalam olahraga, termasuk dalam kemampuan dribble pada permainan bola basket. Apa yang telah dihasilkan dalam penelitian ini, yang memperlihatkan adanya kontribusi panjang lengan dengan kemampuan dribble pada permainan bola basket, menjadi rujukan dalam meningkatkan kemampuan dribble pada permainan bola basket. Oleh karena itu, dengan pentingnya panjang lengan, maka dapat dipahami bahwa panjang lengan memiliki hubungan yang didasarkan pada kontribusi dengan kemampuan dribble pada permainan bola basket.

4. Kontribusi koordinasi mata tangan, kekuatan lengan dan panjang lengan dengan Kemampuan dribble pada permainan bola basket

Dari hasil pengujian hipotesis keempat yang menunjukkan adanya kontribusi secara simultan antara koordinasi mata tangan, kekuatan lengan dan panjang lengan dengan kemampuan dribble pada permainan bola basket siswa SMA Negeri 2 Bone 0.71. Selain faktor koordinasi mata tangan, kekuatan lengan dan panjang lengan yang memiliki kontribusi dengan kemampuan dribble pada permainan bola basket, masih ada faktor lain yang mempengaruhinya. Hal ini terbukti dengan nilai koefisien determinasi kontribusi koordinasi mata tangan, kekuatan lengan dan panjang lengan secara bersama-sama terhadap kemampuan dribble pada permainan bola basket hanya mencapai $71,20 \%$.

\section{UCAPAN TERIMA KASIH}

Pada kesempatan ini berterima kasih kepada Kepala SMAN 2 Bone sebagai tempat penelitian dan kepada Yayasan Pendidikan Ujung Pandang dalam mensponsori dalam penelitian ini serta seluruh pihak yang terkait.

\section{SIMPULAN DAN SARAN}




\section{Jurnal Celebes Education}

Dari hasil peneilitan yang telah diuraikan adalah terbukti terdapat koordinasi mata tangan, kekuatan lengan, dan panjang lengan terhadap kemampuan dribble pada permainan bola basket. Faktor kemampuan fisik yaitu koordinasi mata tangan, kekuatan lengan dan panjang lengan perlu dikembangkan dan diperhatikan dan dapat dijadikan acuan dalam memilih bibit atlet untuk dilatih ke arah pencapaian prestasi.

\section{DAFTAR RUJUKAN}

Ahmadi, N. 2007. Permainan Bola Basket. Surakarta:Era Intermedia.

Haryono, S. 2009. Buku Pedoman Praktek Laboratorium Matakuliah Tes dan Pengukuran Olahraga .Semarang: Prodi Pendidikan Kepelatihan Olahraga FIK UNNES.

Islahuzzaman, N. 2010. Identifikasi Bakat Usia Dini Siswa SD-SMP Surakarta. Jurnal Paedagogia. 13 (1), Februari 2010, 61-69.

Ismaryati. 2009. Tes dan Pengukuran Olahraga.Surakarta: Sebelas Maret University Press.

Kosasih, D. 2010. Fundamental Basketball First Step To Win. Semarang: Karangturi Media, 2010.

Nurhidayah, N., \& Sukoco, P. 2015. Pengaruh Model Latihan dan Koordinasi Terhadap Keterampilan Siswi Ekstrakurikuler Bola Basket SMPN I BANTUL. Jurnal Keolahragaan, 3(1), 66 - 78.

Oliver, J. 2007. Dasar-dasar Bola Basket. Bandung: PT Intan Sejati.

Pasau, Anwar. 1986. Pertumbuhan dan Perkembangan Fisik. Ujung pandang: FPOK IKIP Ujung Pandang.

Suharjana. 2013. Kebugaran Jasmani.Yogyakarta: Jogja Global Media.

Sukadiyanto \& Muluk, D. 2011. Pengantar Teori dan Metodologi Melatih Fisik. Bandung: Lubuk Agung.

Undang Undang Republik Indonesia No 3 Tahun 2005 Tentang Sistem Keolahragaan Nasional.

Wissel, H. 2000. Basketball Step to Success (Bolabasket: Langkah Untuk Sukses). Penerjemah: Bagus P. Jakarta: Raja Grafindo. 